\title{
Requestioning the Evil/ Good Woman's Representation in Algerian Story-Telling: A Gender-Based Analysis
}

\author{
Fatma Zohra Mebtouche-Nedjai \\ Lecturer Professor (MCA) of Sociolinguistics, High school of Fine Arts of Algiers, Algeria \\ conferencegender@gmail.com
}

\author{
Doi:10.5901/mjss.2015.v6n4s2p478
}

\section{Abstract}

\begin{abstract}
Many story-tellings in Algerian oral culture, portrayed woman as a monster, (Frobenuis 1996), (Lacoste -Du-Jardin, 1991, 2005), a cruel stepmother (Mammeri, 1996) and (Bourayou, 2003) or as a clever creature, (Mammeri, 1996). This duality is interesting to analyze because it could bring into light that the evil is not inherent to the nature of woman but contingent upon the context, on the one hand. On the other, the female's positive behavior could be perceived as a resisting and self-defense strategy against the ideology of the oppressor that could stand for the struggle of power between man and woman. The purpose of this paper aims at highlighting through a feminist approach how power relations between male and female are displayed in some Mammeri's tale (1996)namely, La fille du charbonnier' and Colombe Blanche and how the storying process transformation affects the actors' actions to pinpoint the dynamics that shaped identity display. As far as the methodology is concerned, a multidisciplinary approach will be used: Propp's model analysis to explore the functions of the characters, and Critical Discourse Analysis will be applied to deconstruct the different meanings of woman's representation in Kabyle tales. The results reveal, among others, that woman's power can exist only if it does not threat man's power. Besides this, it may be used either against or for man's empowerment.
\end{abstract}

Keywords: evil /good woman- tales- power relations.

\section{Introduction}

Tales, legends and myths highly contribute in constructing the social imaginaire, social attitudes and meaning of the world. Most of societies agree upon the fact that besides its entertaining function, storytelling aims at passing in pleasant way some moral values and constructing some representations depending on different contexts (Griaule \&all, 1984) and story teller's ideology (Nagy, 1984). Among these values, two dichotomist representations of the evil/good are in a recursive way associated with woman in storytelling, in general, and in Kabyle tales, in particular. Many tales in Algerian oral culture, portrayed woman either as settut, (a witch), teryel (ogress) temgart (old woman), (Lacoste -Dujardin, 1991, 2005), an eater of her children, monster (Frobenuis 1996) or as a jealous and cruel stepmother (Mammeri, 1996,). However, the good image of woman standing for wife is at very low frequency found in tales as in La fille du charbonnier and Colombe blanche (Mammeri, 1996), which represent the corpus of this paper.

The purpose of this study aims first at bringing into light the positive portray of these wives who can empower/ or disempower husband thanks to the power of knowledge. Secondly, a specific focus will shed light on the seditious transformational storying process upon the male characters' behaviour. As far as the methodology is concerned, an interdisciplinary approach including namely Propp 's analysis combined with the content-based critical discourse of the corpora within Gender and Language perspective will be applied. This choice is motivated by the fact that Propp 's analysis seems suitable to Kabyle tales for its flexibility as Haddadou contented (2009: 129). Nevertheless, the analysis of the sequences of the tales we intend to follow, will not be presented on the basis of their functions as Propp did but on the ground of their social /or individual effect in terms of equilibrium and disequilibrium. In other terms the triptych: Lack disequilibrium and re- equilibrium structures the tale in general in three main phases- an event that leads to the transgression of the established order leading to disequilibrium, -then an attempt to repair the moral or physical prejudice- finally success to reset the prior equilibrium- (Pentikaïnen, J. 1964: 533). While the content-based critical discourse analysis within Gender and Language lens will enable us to discuss how power relations between male and female characters are displayed at surface and deep level. The paper includes four sections: methods, material, analysis and discussion. 


\section{Review}

Even if the primary function of tales is entertaining children and adults, it is above all a channel of transmitting the collective memory. It aimed at instilling, in a given community knowledge and experiments of its myths, values, taboos, frights and anxieties (Haddadou, 2009: 133)(Trans. Mine). More importantly, tales are obviously vehicles of the « universal moral » in terms of do the good, be good, be just underpinned by local ideological/ religious coloration, a fact that underlines the importance of context in tales analysis reports (Haddadou, 2009: 133). Many models of storytellinganalysis are proposed by Propp, (1968), Greimas, (1986)and William Labov and Joshua Waletsky's (1997), among others. We will restrict an overall presentation to theThe Propp 's model.

\subsection{The Propp 's model}

Propp's model is based on sequences and functions which are actualized differently. Propp found out that different characters in Russian wonderful tales perform same actions that are enacted differently (Propp, 1984: 73). The latter illustrates his idea as follows: "Ex if the hero leaves home in quest of something and the object of his desires is far away he can reach it by a magic horse, eagle, magic carpet, flying ship, astride the devil (Propp, 1984: 73). Besides this, "He identified the roles of villain, helper, donor, princess and her father, dispatcher and hero (Propp, 1984: 77-83). Globally, Propp 's analysis based on sequences can be summed up in the triptych: equilibrium -disequilibrium and re- equilibrium. In other words, it is the transgression of the established order which breaks the social equilibrium leading to disequilibrium and the attempt of repairing the transgression will reset the equilibrium. (Pentikainen, J. 1964: 533) contended that the constant operational roles in the dramatis personae of Vladimir Propp identified- 1) the upsetters of a state of equilibrium(breakers of the norms)- 2) those who experienced a crisis are those to whom the state of disequilibrium primarily applies, -3) restorers of equilibrium called mediators' -However, Levi Strauss reproaches to Propp that his analysis is made in isolation by ignoring the impact of the context in the tales construction reported (Haddadou, 2009: 125) Thus, taking into account the patriarchal Kabyle context we will apply Propp's model for its flexibility as Haddadou did for some Kabyle fairly tales (2009: 129)with the combination of a gender-based perspective underpinned by the dominant model.

\subsection{The dominant model.}

Indominance modelapproach women are seen as powerless speakers in man-woman interactions because of social privileges conferred to man (Zimmerman \& West, 1975; West, 1984, Romaine, S. 1999). Thus, the advocates of dominance model refer to difference as power relation between male and female and reformulate the question' how does language reflect, construct and maintain male dominance? Others have shown how social systems restrict women's freedom of choice and action (Tong 1989, Cameron, 1996). Furthermore, D. Cameron explains how specific preferred linguistic practices, she called, 'verbal hygyiene', establish the legitimacy of authoritarian variety of norms of correctness with the different ideological underpinnings. She defines verbal hygiene as a term to be used 'for a diverse set of normative metalinguistic practices based on a conviction that some ways of using language are functionally, aesthetically or morally preferable to others. (1996: 32). In the same stream, Bourdieu referred to verbal hygiene in its forms of 'censored' and or 'euphemized 'speech as a manifestation of symbolic violence which is 'a gentle violence' that maintains at the same time the direct and hidden domination. (Bourdieu, 1994: 162)However, domination principles are not predictable as, J. demonstrates: other underlying factors can affect both woman's and man'speech (Deborah James, 1998: 119)

\section{Data}

Extracted from (Mammeri, M., 1986) the translated synopses of the two tales under study, La fille du charbonnier (1986: 25) (The Coalman's Daughter) and Blanche Colombe (1986: 43) (The White Dove) will be presented in the following.

\subsection{Synopsis of La fille du charbonnier (The Coalman's Daughter) (Trans. Mine)}

A king used to weekly address a group of people using riddles to be decoded in a week on pain of death. A coalman, present, reported the riddle to his youngest daughter whose right answer led the king to marry her. However, from the very first day of their marriage, he warned her that he will expulse her if she dares defying his power. Once, standing in 
her palace terrace she heard two friend's discussion in which one of them complained about the kings' misjudgment who condemned him in spite of his innocence. After having listened to all the details, the king's wife suggested a solution to the victim that proved his innocence. Amazed by the strong argument of the former victim, the king attempted to know who provided it. The man answered that he simply heard a voice coming from a terrace in a specific place. He grasped that the indicated place was that of his palace, and therefore inferred that the argument stemmed from his proper wife. Very upset by her transgression, the king decided to repudiate her. Nevertheless, he permitted her to take the most valuable thing she wanted. Before living she asked him to share a farewell dinner during which she put a soporific powder in the meals. Then, the king was transported sleepy in a coffer to her new residence. When awaken, he asked herabout his presence there. She explained that as she was allowed to take what she wanted, she chose his company as being the most precious for her. Profoundly touched by this mark of love and subtlety, he decided to forgive her. Thus, they lived happily ever after.

\subsection{Synopsis of Blanche Colombe (The White Dove)(Trans. Mine)}

The cruel stepmother pushed the king, her husband, to expel his son from the kingdom assuming that he represented a threat to his power. After a long wandering, the prince entered into a big palace in which he felt asleep. At his waking up, he saw on the edge of the window, a white dove which was metamorphosed into a beautiful girl when landed on the floor. As she was also exiled by her father, they decided to marry each other. The news reached the stepmother who wrote a letter in which she congratulated him for his wedding, but suggested to him to marry Aicha Bent Roums to be happier. Both understood her trap, but his wife urged him to accept the challenge and gave him a ring of power 'un anneau de puissance' to use Lacoste Dujardin's term (2010: 18), that would help him to get out of any difficulty. After having satisfactorily met the difficult conditions of the king, he came back home with his new bribe Aicha bent Roum. Then, the stepmother told him to marry Hita, the daughter of the king's spirits. With the help of his two wives, he managed to defeat all the king's obstacles and marry Hita. In another letter, complaining of their loneliness, the stepmother begged him to return to his father's kingdom. When the king saw the three son's wives, he was struck by their beauty and wanted them in his palace. Although jealous of them, the stepmother approved his desire of possessing them, but not before killing the prince. Thus, she invited the prince for a dinner in order to empoison him. However, Blanche Colombe warned the prince against her killing intention and prevented him from eating the food. Having failed in her plot, she proposed to her husband to take him to hunting with the purpose of abandoning him hungry, thirsty and blinded in the desert, before he would dethrone him because of his magic power. The king did what his wife told. Having guessed that the prince was in danger, Hitta called the spirits of her father and send them to attack the king and his wife who were killed in a ferocious battle. The prince and his three wives lived happily ever after.

\section{Analysis of Data}

The analysis includes a broadly formal Propp 's model analysis to identify the main functions of the characters which indeed are in a recursive way leading to the social equilibrium/disequilibrium or re-equilibrium besides to the discourse analysis to unveil the hidden agenda of power relations.

\subsection{Propp 's Model Analysis of la Fille du Charbonnier (The Coalman's Daughter)}

1- The king's threats of his subjects(to kill them if they do not disambiguate his complex riddles: disequilibrium.

2- The coalman's daughter successful answer and her marriage with the king: equilibrium.

3- The coalman's daughter' $s$ transgression(the deal of never publicallychallengingthe king' power). (disequilibrium).

4- The King's sanction: intention of divorce (disequilibrium).

5- Helper: a) The wisdom and knowledge of the coalman's daughter(as an implicit helper)b)The soporific powder.

6- Reconciliation between the husband and the wife: re-equilibrium.

The analysis of this tale informs that the social context in which the king stands for the authoritarian character who threats, kills and divorces-clearly, stemmed from patriarchal system as (Bourayou, 2003: 72) underlines. Adds to this the nomination of the Coalman's daughter explicitly refers to the patriarchal affiliation. Obviously one expects valuing/devaluing male and female respectively. On the opposite, the female character possesses a highly convincing and positive voice. La Fille du Charbonnier is the central actor who generates both equilibrium and disequilibrium because of her power of knowledge to use Foucault's concept(1972) concept. So, the same character fulfilled many 
functions in different sequences, displaying, therefore, power of knowledge, transgression, and wisdom that revealed a fairly great agency. This result overlapped with another Algerian tale's analysis, Lunga studied by A. Bourayou(2003: 73) who affirmed that the extraordinary protection of the heroine is due to her mental competence.

\subsection{Propp 's Model Analysis of Colombe Blanche (The White Dove)}

1- The prince's expulsion (by his father under the manipulation of his stepmother (separation): (lack) disequilibrium.

2- Recursiveness of the villain's/opponent's deeds: (stepmother's plotting, the father's jealousy, the attempt of homicide): disequilibrium.

3- Helper: Magic power (White dove a magic creature, magic ring, the princess and her powerful father, (Aicha Bent Roum) and (Hita, the daughter of the king's spirits) and the Wiseman.

4- Victory of the prince (death of the villain and end of rivalry: equilibrium

5- Return of the Hero: re-equilibrium

The analysis of this tale underpins that three female characters using either their proper magic power or that of their father supported the prince to defeat the villain stepmother.

\section{Analysis}

What makes the sequences equilibrium -disequilibrium- helper - re-equilibrium endlessly repeated in the two analyzed tales ? Indeed, what is interesting for us is to make a triangulation between the Propp 's analysis, the dominant model which either silenced woman on behalf of gentle violence or devalue her by presenting her as the negative force (the villain) and the storying process transformation that affects the feminine/masculine actors 'actions to pinpoint the dynamics that shaped identities display. It seems that the seek for power for both cross /same sex relations is behind all this violence might be real or symbolic. In both tales the power relations are enacted between same/cross sex actors; e.g. from king towards his subjects and from king towards his wife in the first tale, and from king towards his son, and from stepmother against the king' son in the second one. This issue raised the question of visibility/invisibility of woman's/man's power.

\subsection{Visibility/Invisibility of Woman's Power}

la Fille $d u$ Charbonnier story telling showed a feminine heroine, a fact that is rare in tales as argued by Lacost Dujardin,. Only $5 \%$ of female characters are positively portrayed. The following analysis will show how woman can reach visibility through the power of knowledge and become a restorer of equilibrium. The power of $L a$ fille du charbonnier, standing for the good woman was depicted in many ways in this tale. First, because of her intelligence, she gained visibility. The king married her since she was the only one to be able to decipher his figurative discourse. Thus, her marriage with the king promoted her to a social ascension. This alliance means also that the woman's power of knowledge is publicly acknowledged. A fact that allows to say that she managed to rub the social difference between upper and lower class(king/coalman's daughter). In this case the woman's power and visibility are publically admitted to such an extent that one can advance that the power relations seem to be neutralized between husband and wife, in appearance, at least. Second, the so called parity between man and woman has momentarily restored the social disequilibrium generated by the difference between social classes, the poor and the rich in the first part of the tale.

However, this re-equilibrium remains fragile by a deeper oppressive man's attitude that excludes woman's competitiveness. Although, the king appreciated la Fille du Charbonnier cleverness, he imposed upon her a restriction stating that she should never show publically her supremacy over him or defy his power by claiming from the very first day: "Je sais que de tous les hommes, de toutes les femmes qui habitent mon royaume, tu es la seule à pouvoir, le cas échéant, me damer le pion. Mais je t'avertis: je suis le roi et jamais je n'admettrai que ta parole ait barre sur la mienne, en quelque occasion que ce soit; " (Mammeri, 1996: 32). (I know that among allthe men and women living in my kingdom you are the only one who can outwit me, but Iwarn you, lam the king and I will never accept it, whatever the circumstances are). (Trans. Mine). In spite of this warning, his wife could not refrain from interfering in his affairs, though in an indirect way. By doing so, she transgressed the sacred king's authority and legitimacy of ruling which was believed to be above any suspicion, leading, therefore to disequilibrium followed by a sanction, e. $g$ the wife's expulsion. The wife's transgression could be perceived either as an act of resistance against the king's empowerment or a sharp sense of duty and justice that pushed her to run the risk of exposing herself to king's disapproval andpunishment. What is important to 
infer from this sequence is that the man's visibility has not to be shadowed by woman's. This recalls the idea that gender relations are shaped on the basis of man's visibility and woman's invisibility in public sphere (Mebtouche Nedjai F. Z. \&Yassine, S., 2014).

\subsection{The Good Woman, Restorer of Right}

Indeed, la fille du charbonnier'stale contrasts the moral values of the goo/bad, the justice/injustice. Thanks to her knowledgeable discourse, she had many times rehabilitated justice; by finding the right answer to the king's riddle, she managed to save the people's life of her community who used to be killed because unable to find out the answers. In addition to that, she helped the innocent man, victim of his opponent's lies recover his right by suggesting to him a strong argument. And finally, she saved her couple from dissolution by using a strategy to counter the king's abusive authority and his decision of repudiating her. Nevertheless, her last triumph was made possible only because, it seems, that the story teller, for patriarchal ideology, that aims at shaping the supremacy of man's virtuosity, came to the king's rescue by presenting him as someone mild in his punishment. Obviously, the wife's expulsion was smoothened, to some extent, by the king's generosity who allowed her to take what she wanted before leaving. She was clever enough to take advantage of this offer and took him with her claiming that he was the most valuable thing she desired. Here again, the wife was ideally portrayed and reaffirmed the prevailing expectation of what a good wife should be in Kabyle family structure., e. $g$ the one whose responsibility is to look after the social and family bonds. If she were selfish or materialistic, she could have taken valuable jewels, for instance. Thus, thanks to her sensitive choice, she reversed the situation: instead of being separated, both the king and the queen lived happily together for ever. This could be interpreted as a re-equilibrium that has been reached after having rubbed the power relations which are socially constructed and not inherent to the nature of woman and man. Nevertheless, if la fille du charbonnier empowered the woman's image in oral tradition, many other tales satanized her as it will be shown in the following discussion of Colombe Blanche.

\subsection{The Stepmother and the Evil in Blanche Colombe tale}

This tale stressed two antagonist female representations: the evil and the good in forms of binary system that exists between stepmotherhood /motherhood, human /supernatural forces,. The stepmother 's representation is recursively shown as the incarnation of the Evil in many universal storytellings, in general, and in Berber one, in particular. The stepmother symbolized the evil as opposed to the good image of the mother which is widely highlighted in Islamic religion and oral culture of the Maghreb. However, it is fair to mention that stepmother 's existence is due to high maternal mortality rate and not to an established system of remarriages in the Kabyle culture, as Lacoste Dujardin explained. (2010: 52). As an illustration, the negative power of the stepmother is insidious and endlessly repeated. She twice pushed her husband to get rid of her stepson and she herself plotted against the prince'sfour times. First by asking his father to expulse him, then in spite of his idyllic life with his wife Blanche Colombe, she suggested to him to marry Aicha bent Roums and Hita, deeply believing that he would be killed by their respective totalitarian fathers. In fact his successful remarriages drove her mad to a point that she asked him to come back homewhere she unsuccessfully attempted to empoison him. Arguably, the persecution of the stepmother to her stepson, as a symbol of cruelty, is, it seems for us, to stress the absence of the goodness of the mother. Thus, the tale is constructed only to stress and praise the role of motherhood whose absence exposed her orphan to suffering and danger as it is shown in another Algerian tale "la vache et les orphelins'. (Bourayou, 2003: 73). The evil of the stepmother could be justified by her sterility or ' lack', to use Propp's term, leading, thus to family disequilibrium manifested in many ways by hatred against the stepson. Nevertheless, the evil is also embodied in the king's violent actions against his son enacted by his expulsion from the kingdom, abandon in the forest/desert, love rivalry, and attempt of homicide. The totalitarian power of the king in a patriarchal system is oppressive over his subjects be his son seems to be commonly admitted in general because of the power relations between the oppressor/ the oppressed. But in this specific context, the king could by no means be blamed for his violence, since he was acting under his naughty wife's manipulation and, therefore, was considered as irresponsible. But the wife's role in another setting, could empower her husband as Blanche Colombe did.

\subsection{The Wives and the Goodin Blanche Colombe tale}

On the other, a good woman 's image is mediated through the solidarity of the three prince's wives as opposed to the evil one (stepmother) with the difference that the former used supernatural power, namely the magic ring or spirits. The prince's wives strengthening union stressed the ethic superiority of the good which always wins over the evil even if there 
is a need to resort to the help of supernatural forces to defeat it. Another implicit duality is conveyed between passing/ lasting power which respectively refers to the evil/ good. The evil stepmother 's actions were always beaten by the good wives' strategies. The aborted stepmother's plots contrasted with the permanent success of the prince's wives to mean that evil is doomed to failure.

\section{Discussion}

The discourse analysis highlights the inversion of gender-based relations in a patriarchal setting. The dichotomist relation between the good and the bad woman within gendered-based perspective raised the question of whether we should speak of power of decision and power of persuasion in the same way. Is the art of speaking matched with the art of manipulating? What is the difference between power and influence. Women are viewed in Greek antic mythology as 'manipulatrices de porcelets'. (porcins'manipulators). Could we apply manipulation to the stepmother, and influence' to the coalman's daughter and the prince' wives? In this respect,. the two female heroines, la fille $d u$ charbonnier and Blanche Colombe are endowed with a positive force enacted through their power of knowledge be respectively intellectual or magic, whose influence upon their husband's decision taking was used to restore social / individual equilibrium unveiling thus, an active feminine agency

\subsection{A dominant representation of woman's agency.}

It is important to say thatthe antagonists in these tales were women who showed agency and power whether positive or negative and the subjects on whom this power was exerted were men: the king/the prince. Even if in La fille $d u$ charbonier, the king appeared relatively active but in negative way as he took bad and abusive decisions regarding his partial judgment or his wife repudiation. Similarly, in Blanche Colombe, the king was presented as a thoughtless individual in his wife's hands. In the same way the powerless prince was dictated the strategies he had to follow to avoid the tyranny of his stepmother's intrigues. In contrast, the former tales focused on the woman's mediation which rehabilitated justiceby stopping the king's abusive decisions of killing people unable to answer his riddles or by redressing the king's misjudgment when he condemned the innocent. This reading raised the issue of visible/ invisible power and power vs. manipulation. Who possesses the power of decision in Kabyle society, man or woman? The contradiction is undeniable if we assume that in the Kabyle tribal patriarchal system, it is the man's authority which is the most dominant, (Bourdieu, 2000)while these story-tellings denied the so-called power to man's identity. It is therefore, possible to accept the truth that, in depth, the Kabyle society is woman- governed as Mouloud Feraoun has already advanced(1957: 60). Obviously, the phrase 'in depth', could be matched at level of speech act with implicit discourse. As a case in point let's recallthat the strategic discursive tool of La fille du charbonieris basically expressed in reported speech; she never affronted the king, on the opposed, she addressed him by using different mediators. For example, she sent her father to transmit the right answer of the riddles. As for the victim she addressed first to him hidden in her palace terrace.

She even said to him when he looked up at the direction from which the voice came "Vous n'avez pas besoin de me voir, dit la reine, l'essentiel est que vous m'entendiez et que vous vous conformez très exactement à ce que j'ai à vous dire" (Ibid, p. 35) (There is no need of seeing me. What matters is that you listen carefully to me and apply everything I tell you). (Trans. Mine.) So, her contribution to restore justice was achieved through a metaphoric discourse she dictated to the victim who repeated it in his turn to the king. Besides, seeking for a reparation for her transgression she wanted to declare her love to the king in a subtle way. After having made him asleep, she took him from his palace to her new residence. When he was awaken she argued that her action was motivated by the fact that he chose to take him as being the dearest to her. Here again she avoided a frontal transaction to reach a reconciliation with her husband. All these practices could be interpreted as what Cameron, 1996: 32) explains, 'verbal hygyiene' practices which circumvented the legitimacy of authoritarian variety of norms of correctness with the different ideological underpinnings. This observation overlaps with our research, showing that in Algerian context woman avoided what we considered as the linguistic taboo and privileged implicit discourse and euphemisms. (Mebtouche Nedjai, 2008). Finally, it is possible to affirm that woman's visibility / invisibility is genderly rule-governed. The contradiction to be underlined in the king's behavior of the first tale, is that he was happy to marry a bright woman to enhance his narcissistic face, as a pleasant décor for example, but not ready to share her interfering in ruling public affairs. This could join the result reached in our thesis stating that some men choose educated girls to marry them but they prevented them from working and claiming knowledge visibility. (Mebtouche Nedjai, 2008). Indeed woman's power is still positioned in the hidden place, it seems, as it is conveyed through this tale although it manages to create some transformation. 


\subsection{Storying Process Transformation}

As above mentioned the function of tales not only goes beyond entertainment and construction of meaning of the world but it is also involves transforming the characters'identity due to the storying process as well. In these lines, Haddadou (2009: 127) reported that Larivaille held that what counted was the succession of events and their transformation occurring during the story telling process. For example, the authoritarian king 's identity displayed at the beginning of $\mathrm{La}$ fille $d u$ charbonierhas moved from a rigid to a more flexible one during the evolution of the tale. He twice accepted to do self criticism by first, reconsidering his wrong judgment and second, cancelling his intended divorce influenced by the highly strategic discursive skill of the heroine. In Blanche Colombe, the weak prince has been empowered thanks to his wives 'help and solidarity. By the end of the tale he managed to free himself from Oedipus complex (after having killed his father -according to psychoanalytic analysis -) and gain his place symbolic or real. Is this the magic of tales where no fixed borders existed between the possible/impossible or is it reflection of reality?

\section{Conclusion}

The analysis revealed unexpected results regarding man's vulnerability, and woman's empowerment partly, and the negotiation of place which is endlessly in process for both male and female actors, partly. It is fair to recall that in Kabylie women are the recipients, and transmitters of story telling which are denigrated by men calling them ' el karef' or non sense stories as opposed to man's knowledge. In this case why women are satanized in most Kabyle tales? In fact even if women are represented as monsters and frightening creatures in many Kabyle fairly tales as recorded in the volume Three of Frobenius or as the evil stepmother, this should not be understood as the satanization of woman's representation but on the contrary as a symbolic violence that woman instill through the process storying standing for self affirmation claim and resistance against a masculine cultural and social order as Lacoste- Dujardin argued (2011).

Moreover, considering the idea that power relations within gender perspective are reversed in the analyzed texts, we advance the hypothesis stating, that there is a deep feminine desire to infantilize man by presenting him as powerless creature. Is not this another counter power against man's controlling woman that woman wanted to create through the fabric of story telling. ?Thus, it is possible to affirm that the Propp's analysis of the two tales helped understand the hidden agenda of Kabyle oral culture regarding the gender relations. Indeed, whether we consider woman's power as referring to symbolic violence, (monster), knowledge, (La fille du charbonnier) or magic (Colombe -blanche) does not bring an added value to woman but more importantly underlines how the storying process does play a role in the construction of the meaning of the world and how it participates in constructing the self and social identity too. Finally, the good or the evil woman's representation in these tales could be a result of woman' s empowerment -either hidden or acknowledged- which represents a means of resistance in order to restore the social equilibrium which could be broken at any moment by the male so-called legitimate power and leading, thus to disequilibrium;

\section{References}

Amrouche, M. T. (1969). Le grain magique, contes, poèmes et proverbes berbères de Kabylie. Paris: Maspéro.

Bergall, V. L., Freed, F. Rethinking Language and Gender Research Theory and Practice, 98-125. U. SA: Longman. Bourayou, A. (2003).

Les contes populaires algériens d'expression arabe. Alger: OPU. Bourdieu, P. (1994). 'Structure. habitus, power; basis for a theory of symbolic power'. In: Dirks, N. B., Eley, G., \& Ortner, S., B, A reader in contemporary social theory. 155-199.

United Kingdom: Princeton University Press. Bourdieu, P. (2000).

Esquisse d'une théorie de la pratique, procédé de trois études ethnologiques. France: Ed. du Seuil. Calamie-Griaule G. \& all. (1984). '

De la variabilité du sens et du sens de la variabilité in Qu'est ce que le conte? Le conte pourquoi? comment? Folktale....why and how?Actes des journées d'études en littérature orale. Analyse des conte- problèmes de méthode.. 201-226.

Paris: CNRS. Deborah J.. (1996). 'Women, Men and Prestige speech forms; a Critical review'.

In: Bing, J. M. \& Bergall, V. L., Freed, FRethinking Language and Gender Research Theory and Practice, 98-125. U. SA: Longman. Feraoun, M. (1957).. La terre et le sang. Paris: du Seuil. Foucault, M. (1980).

Power /knowledge: selected interviews and other things 1972-1977 Pantheon Books: Colin Gordon www; books; google. dz/books/ 7 december 2014. Frobenius, Leo (1921), Contes kabyles, tome III, Le Fabuleux, Trans. Mokran Fetta, Aix-en-Provence: Edisud, 1996.

Greimas, A. J. (1966). Sémantique structurale. Paris: Larousse. Haddadou, M. A. (2009). Introduction à la littérature berbère Introduction à la littérature berbèresuivi d'une Introduction à la littérature kabyle. Haut Commissariat à l'Amazighité. Tizi Ouzou: les Oliviers

Labov, William, and Joshua Waletsky. [1967] 1997. Narrative analysis: oral versions of personal experience. Journal of Narrative and Life History 7 (1-4): 3-38. 
Lacoste-Dujardin, C. (1986). Des Mères contre les Femmes: Maternité et Patriarcat au Maghreb. Paris: Editions la Découverte.

Lacoste-Dujardin, C. (1991). Le conte kabyle, étude ethnologique. (seconde édition). Alger: Bouchène.

Lacoste -Dujardin, C. (2010). La vaillance des femmes: Les relations entre femmes et hommes berbères de kabylie. Alger: Editions Barzakh..

Mammeri, M. (1996). Les contes berbères. France: Pocket Jeunesse. Mebtouche Nedjai F. Z. \&Yassine, S. (2014).

'Political Empowerment of the Algerian Woman: A Sociolinguistic Analysis' (pp. 93-116), inPromoting women's rights \& gender equality in the middle east and north africa, edited by: Dr. E. Stetter, C. Reuter. Editors: J. Tánczos, M. Claassens, M. Vingerhoedt, S. Hammerton, Copyright: FEPS Solidar.

Mebtouche Nedjai F. Z., (2008). Le tabou linguistique: étude sociolinguistique des attitudes des femmes des wilayas de Tizi Ouzou et de Boumerdès (sous la direction de $\mathrm{A}$. Dourari), Thèse de doctorat nouveau régime en Sciences du langage, option Sociolinguistique, Alger, Université d'Alger, Faculté des lettres et des langues, Département de Français de Bouzaréah, Nagy. Olga (1984). 'Some types of comparative tale analysis'. In Le conte pourquoi? comment? Folktale...why and how?, Actes des journées d'téudes en littérature orale.

Analyse des contes- problèmes de méthodes, édité by pp. 231-252. Paris: CNRS. Pentikaïnen, J. (1964). "who creates the structural patterns?" In Le conte pourquoi? comment? Folktale...why and how?, Actes des journées d'téudes en littérature orale. Analyse des contes- problèmes de méthodes, édité by pp.: 528- 542 .

Paris: CNRS Propp, Vladimir. 1984. The structural and historical study of the wondertale.

In Theory and History of Folklore, edited by A. Liberman. Manchester: Manchester University Press. Romaine, S. (1999). Communicating Gender. New Jersey: Laurence Zimmerman, D. and West, C. (1975). Sex roles, interruptions and silences in conversation. 